\title{
Species delimitation of Melia dubia Cav. from Melia azedarach L. complex based on DNA barcoding
}

\begin{tabular}{|c|c|}
\hline Journal: & Botany \\
\hline Manuscript ID & cjb-2017-0148.R1 \\
\hline Manuscript Type: & Note \\
\hline Date Submitted by the Author: & 01-Jan-2018 \\
\hline Complete List of Authors: & $\begin{array}{l}\text { Sivaraj, Irusappan ; SRM University, Department of Genetic Engineering } \\
\text { Nithaniyal, Stalin ; Madras Christian College, Department of Plant Biology } \\
\text { and Plant Biotechnology } \\
\text { Bhooma, Varadharajan ; SRM University, Department of Genetic } \\
\text { Engineering } \\
\text { Senthilkumar, Umapathy ; SRM University, Department of Genetic } \\
\text { Engineering } \\
\text { Parani, Madasamy; SRM University }\end{array}$ \\
\hline $\begin{array}{r}\text { Is the invited manuscript for } \\
\text { consideration in a Special } \\
\text { Issue? : }\end{array}$ & N/A \\
\hline Keyword: & $\begin{array}{l}\text { Melia azedarach, Species complex, DNA barcodes, ITS2, Bayesian } \\
\text { Phylogeny }\end{array}$ \\
\hline
\end{tabular}


Species delimitation of Melia dubia Cav. from Melia azedarach L. complex based on DNA barcoding

Irusappan Sivaraj $^{1 \#}$, Stalin Nithaniyal ${ }^{2 \#}$, Varadharajan Bhooma ${ }^{1}$, Umapathy Senthilkumar ${ }^{1}$, Madasamy Parani ${ }^{*}$

\# These authors contributed equally to this work.

${ }^{*}$ Corresponding author

${ }^{1}$ Centre for DNA Barcoding, Department of Genetic Engineering, SRM University, Kattankulathur 603203, India.

${ }^{2}$ Department of Plant Biology and Plant Biotechnology, Madras Christian College (Autonomous), East Tambaram, Chennai 600 059, India.

Running Title: DNA barcoding of Melia azedarach L. complex 


\begin{abstract}
The genus Melia L., which belongs to the 'Mahogany' family Meliaceae, is a source of important phytochemicals with marked medicinal properties. Species identification in Melia is complex due to the existence of overlapping morphological features. Though Melia dubia Cav. is listed as a synonym of Melia azedarach L., it is not clear from the available literature whether they are the same species or different, and the species complexity still remains unresolved. In the present study, ten accessions of $M$. dubia and M. azedarach were analysed by DNA barcoding using three chloroplast DNA markers ( $r b c L$, matK, and trnH-psbA), and one nuclear marker (ITS2). Intra-specific divergence was not found in any of the four markers. However, the inter-specific divergence between M. azedarach and M. dubia ranged between $0.3 \%(r b c L)$ and $4.7 \%$ (ITS2) for individual markers, and for the combined dataset, it was $8.5 \%$. Among the four markers, ITS2 was found to be the most suitable marker for differentiating $M$. azedarach and M. dubia. Parsimony analysis of the DNA barcoding data showed a clear segregation between $M$. azedarach and M. dubia as distinct monophyletic clades in all the markers, except the $r b c L$ marker. Our results based on Bayesian analysis of the concatenated dataset strongly support the view that $M$. dubia be considered a distinct species; not a synonym of $M$. azedarach
\end{abstract}

Keywords: Melia azedarach; Species complex; DNA barcodes; ITS2; Bayesian Phylogeny 


\section{Introduction}

The genus Melia L. of Meliaceae (Mahogany family) contains hardwood deciduous tree species that are widely distributed in the tropical and subtropical regions of the world (Mabberley 1984). In Meliaceae, the species of Melia are distinguished by indumentum of stellate hairs in young plant parts, bi-tri-pinnate leaves, flowers on panicle inflorescence, 3-8lobed or sometimes capitate stigma, 1-2-seeded drupe, and stony endocarp (Gamble 1915; Hajra et al. 1997). This genus is of great ecological, economic, and medicinal importance in the development of organic pesticides and fertilizers, agro-forestry, and herbal formulations. It is gaining importance due to a large demand for phytochemicals such as alkaloids, steroids, flavonoids, saponins, essential oils and limonoids, which have antimicrobial, insecticidal, and nematicidal properties (Kumar et al. 2003; Nagalakshmi et al. 2003; Kamaraj et al. 2010; Dharmalingam et al. 2014). Natural health products derived from Melia have been reported to be useful in treating diabetes, inflammation, and ulcers (Sharma and Singla 2013; Gopal et al. 2015). Melia is also in high demand for its fast-growing wood with good physical and mechanical properties, which are suitable for manufacturing facilities that make plywood, furniture and paper (Saravanan et al. 2013).

Despite its multipurpose values and importance, species level diversity within Melia has not yet been completely clarified. The taxonomic status of Melia is uncertain in Asia, Africa, America, Australia, and Europe owing to variable anatomical and morphological features, ecotypes, and karyotypes (Ghosh 1968; Mabberley 1984; Sharma et al. 2012). The genus Melia was first recognized in Hortus cliffortianus, and it consisted of two species, $M$. azedarach and M. azadirachta (Linnaeus 1738). Later, M. azadirachta was moved to a new genus (Azadirachta) based on the pinnate leaves (bipinnate in Melia) and the species was named as $A$. indica A. Juss (De Jussieu1830). Species of Melia are native to the Indo-china regions, and they were introduced to several other countries for their timber value. Melia 
azedarach L. is widely distributed throughout the tropical, sub-tropical and warm temperate regions, and it is naturalized in Africa, Australia, India, China, southern Europe, the USA, Mexico, Central America, the Caribbean, and many Pacific islands. Melia dubia Cav. is distributed in south-eastern Asia, India, China, Japan, and Australia (Mabberley 1984; Husain and Anis 2009; Hasegawa et al. 2010). Species complexity exists in Melia due to the occurrence of cultivated varieties, and morphotypes, and therefore, the number of species in this genus remains to be conclusively determined. Inter-species differentiation between the Melia species in China is ambiguous, and it is not clear whether M. toosendan Siebold exists as a separate species (Liao et al. 2016). Gamble (1922) reported M. azedarach L., M. birmanica Kurz, M. composita Willd., and M. indica (A. Juss.) Brandis from India. Mabberley (1984) has reviewed the nomenclature of Melia, and treated all the cultivated varieties and morphotypes such as M. sempervirens (L.) Sw., M. dubia Cav., M. composita Willd., M. toosendan Siebold, M. australasica A. Juss., M. volkensii Gürke, M. bukayun Royle and $M$. japonica G. Don. as one species under M. azedarach. In the Flora of India (Hajra et al. 1997), M. birmanica and M. composita were synonymized under M. dubia, and M. azedarach and M. dubia were recognized as two distinct species. These two species could be clearly distinguished based on deep purple (lilac) honey-scented flowers in M. azedarach, and white inodorous flowers in M. dubia. The fruits of M. azedarach are globose-ellipsoid measuring $1.0-1.5 \mathrm{~cm}$ long, while that of M. dubia are ovoid-ellipsoid measuring $2.5-4.0$ cm long (Table 1). Cavanilles (1789), Sasidharan and Sivarajan (1996), Nagalakshmi et al. (2001), and Murugesan et al. (2013) have also considered them as different species. In contrast, many studies have considered only $M$. azedarach as an accepted species (Dassanayake 1995; Ahmed et al. 2012; Dharmalingam et al. 2014; Lake 2015). The existing complexity of whether M. azedarach and M. dubia are the same or different species can be 
resolved using DNA barcoding, which was reported to be efficient in species differentiation and identification of cryptic species (Ragupathy et al. 2009; Liu et al. 2016).

DNA barcoding uses short, standardized, universal DNA regions for species identification (Hebert et al. 2003). Differentiation of congeneric species by DNA barcoding requires higher inter-specific divergence than intra-specific divergence in all pair-wise species combinations (Vassou et al. 2015; Umapathy et al. 2015). Three chloroplast DNA barcode markers ( $r b c L$, matK and trnH-psbA) and one nuclear DNA barcode marker (ITS2) have been widely used for DNA barcoding in plants (Chen et al. 2010; Hollingsworth 2011; Han et al. 2013; Sundar et al. 2016). We have collected ten accessions of M. azedarach and M. dubia from geographically distant places, and DNA barcoded by sequencing $r b c L$, matK, trnH-psbA, and ITS2 DNA barcode markers to understand the differentiation between the two species.

\section{Materials and Methods}

\section{Plant Collection}

Ten accessions each representing $M$. azedarach and $M$. dubia each were collected from eight different states in India (Table 2). Three accessions of Azadirachta indica collected from Tamil Nadu, India were included as an allied species. All the specimens were identified taxonomically and voucher specimens were deposited to the SRM University Herbarium.

\section{DNA isolation, PCR amplification and DNA sequencing}

Genomic DNA was extracted from $100 \mathrm{mg}$ of fresh leaf tissue using the cetyl trimethyl ammonium bromide (CTAB) method (Saghai-Maroof et al. 1984) with minor modifications (Nithaniyal et al. 2014). The genomic DNA was checked on $0.8 \%$ Agarose gel and quantified. PCR amplification of the DNA barcodes was done using universal primer pairs for $r b c L$ (Zhang et al. 2003; Fazekas et al. 2008), matK (Heckenhauer et al. 2016), trnH-psbA (Kress et al. 2005) and ITS2 (Chen et al. 2010). PCR reaction mixture contained 1X buffer 
with $1.5 \mathrm{mM} \mathrm{MgCl}_{2}, 0.2 \mu \mathrm{M}$ dNTPs, 5.0 pmol primers, 1 unit Taq DNA polymerase (GenetBio Inc., Korea) and $50 \mathrm{ng}$ of genomic DNA. PCR amplification included initial denaturation at $95^{\circ} \mathrm{C}$ for 5 minutes, 30 cycles of denaturation at $95^{\circ} \mathrm{C}$ for 30 seconds, annealing at $55^{\circ} \mathrm{C}$ for 30 seconds, and extension at $72^{\circ} \mathrm{C}$ for 1 minute, final extension at $72^{\circ} \mathrm{C}$ for 5 minutes, and hold at $4^{\circ} \mathrm{C}$. The PCR amplified products were purified using EZ-10 Spin Column PCR Purification Kit (Bio Basic Inc. Ontario, Canada). Sequencing of the PCR products was carried out in our laboratory using Big-dye terminator chemistry and 3130xl Genetic Analyzer (Life Technologies, California, USA) by following the standard manufacturer's protocol. All of the collected accessions of Melia were successfully sequenced, even though they were reported to contain diverse metabolites; these can copurify and irreversibly bind with nucleic acids to affect PCR amplification of the barcode markers (Rawat et al. 2016). Though the mononucleotide repeats were reported to cause problems in sequencing of trnH-psbA marker from plants (Devey et al. 2009), such problems were not encountered in Melia, probably due to smaller size of the repeats and low frequency of occurrence.

\section{Sequence Retrieval from GenBank Database}

The GenBank database of NCBI (https://www.ncbi.nlm.nih.gov/) was searched for the presence of $M$. azedarach and M. dubia DNA barcode sequences. For M. azedarach, 31 sequences representing $r b c L$, matK, trnH-psbA, and ITS2 markers were retrieved. However, for $M$. dubia, only 2 sequences representing $r b c L$ and matK markers were available. In addition, we have retrieved 110 barcode sequences of $r b c L, \operatorname{mat} K, \operatorname{trn} H-p s b A$, and ITS2 markers from closely related species from Meliaceae family to understand the species relationship. The sequences were included only if they were i) tagged with publication in refereed journals or unpublished data from scientists with good publication record in taxonomy, ii) placed in a clade that is appropriate to its taxonomic affiliation, and iii) showed 
proper sequence alignment using MUSCLE algorithm (Edgar 2004) with 70\% threshold. The sequences curated from GenBank database with other details such as voucher IDs and references are given in Table S1.

\section{Phylogenetic Analysis}

The sequences were manually edited for base calling errors using Sequence Scanner Software v1.0 (Applied Biosystems, CA, USA). Intra- and inter-species divergences were calculated using TaxonDNA v.1.6.2. (Meier et al. 2006). Divergence was calculated as per cent divergence $=($ Number of mismatched nucleotides $/$ Total number of aligned nucleotides $) \mathrm{x}$ 100. The basic sequence statistics like conserved sites, variable sites and parsimony informative sites were calculated using PAUP*4.0b10 (Swofford 2002). Phylogenetic analysis was performed individually for each marker using parsimony method, and Bayesian approach was adopted for concatenated dataset.

Parsimony analysis: Heuristic search was conducted with 10000 random addition sequence replicates using Tree Bisection-Reconstruction (TBR) in PAUP. Bootstrap analysis was carried out with 100 bootstrap replicates, each with 200 random additions per replicate. The tree using 50\% majority rule consensus was generated and viewed in FigTree ver. 1.3.1 (http://tree.bio.ed.ac.uk/software/figtree).

Bayesian analysis: Datasets were generated independently for four markers, and included as different partitions in the concatenated dataset. All four markers were combined considering the concordance at their topologies. Evolutionary model was set as mixed in MrBayes 3.2 (Ronquist et al. 2012), and Monte Carlo Markov Chain (MCMC) analysis was performed for $2 \mathrm{M}$ generations. Later, the parameters and trees were summarized into $50 \%$ majority rule consensus tree, and it was viewed in FigTree along with the branch support of posterior probabilities (PP) from the analysis. 


\section{Results}

All the accessions of Melia collected for the current study were DNA barcoded using $r b c L$, $m a t K$, trnH-psbA, and ITS2 DNA barcoding markers. All the sequences were generated from vouchered specimen. In the case of the $r b c L$ and matK markers, open reading frames were found to be intact, and there was no DNA sequence length variation between $M$. azedarach and M. dubia in either of the markers. For the ITS2 marker, good quality sequences were obtained for all the samples, and the DNA sequence length was $459 \mathrm{bp}$ and $464 \mathrm{bp}$ in $M$. azedarach and $M$. dubia, respectively. In the case of trnH-psbA, the maximum and the minimum size of 'A' or ' $\mathrm{T}$ ' mononucleotide repeat was seven, and two, respectively. The mononucleotide repeat sequences did not affect sequencing, and the DNA sequence length was $377 \mathrm{bp}$ and $378 \mathrm{bp}$ in M. dubia and M. azedarach, respectively. All the DNA barcode sequences were obtained full-length for the target region data were submitted to the Barcode of Life Database (www.boldsystems.org) under the BOLD accession IDs SRM001018A to SRM001020J.

Entire barcode sequences were used to calculate divergences separately for individual markers and in combination for all the four markers. Intra-specific divergence was not observed in any of the four markers in M. azedarach and M. dubia. However, total interspecific divergence between $M$. azedarach and M. dubia was found to be $8.5 \%$, and the highest divergence was found in ITS2 (4.7\%) followed by the trnH-psbA (2.0\%), matK (1.5\%), and $r b c L(0.3 \%)$ markers. When the nucleotide composition of each marker was analyzed, the number of parsimony informative sites was also the highest in the ITS2 marker followed by the trnH-psbA, matK and $r b c L$ markers (Table S2).

The parsimony trees constructed using DNA barcode data showed a clear segregation between M. azedarach and M. dubia as distinct monophyletic clades in all the markers, except the $r b c L$ marker (Fig. S1). The phylogenetic tree constructed using the $r b c L$ marker 
contained 33 sequences representing M. azedarach, M. dubia, and M. volkensii. M. azedarach formed a separate clade, which consisted of the accessions from Australia, Austria, Egypt, India, Korea, South Africa, and the United States (Fig. S1a). Accessions of M. dubia from India and Austria formed another distinct clade. M. volkensii from Kenya was differentiated from the $M$. azedarach cluster albeit with very low genetic divergence. The phylogenetic tree constructed using the matK marker contained 26 sequences representing $M$. azedarach, $M$. dubia, and M. volkensii. In this tree, the M. azedarach clade was represented by the accessions from Austria, South Africa, Switzerland, and the USA (Fig. S1b). The M. dubia clade was distinct and included accessions from India and Austria. M. volkensii from Kenya was clearly differentiated from the $M$. azedarach cluster, which formed the basal clade for $M$. azedarach and M. dubia at $99 \%$ bootstrap support. In the case of trnH-psbA marker, the phylogenetic tree was constructed using 25 sequences representing $M$. azedarach, and $M$. dubia (Fig. S2a). M. dubia species were clearly differentiated (99\% bootstrap support) from M. azedarach, which formed a separate clade consisting of the accessions from India, China, Korea, and the USA. The phylogenetic tree constructed with the ITS2 marker contained 28 sequences representing $M$. azedarach and M. dubia. The accessions of these two species formed distinct clades with $79 \%$ bootstrap support. However, the accessions of M. azedarach from India and Korea formed an internal clade. The accessions of $M$. azedarach and $M$. azedarach var. toosendan from China formed a clade within M. azedarach with $99 \%$ bootstrap support (Fig. S2b). A. indica stood as a sister to the genus Melia in all the four markers. In the Bayesian analysis based on the concatenated dataset of all four markers, one clade with the accessions of $M$. azedarach and another clade with the accessions of M. dubia along with the polytomy of the lone accession of $M$. volkensii from Kenya were observed (Fig. 1). The branch support with high PP value (100\%) clearly showed that $M$. azedarach and M. dubia are distinct lineages. An accession of M. dubia reported from Austria was 
clustered within the M. dubia clade that was formed by the accessions from India. Two different lineages were observed within the M. azedarach clade. Cipadessa baccifera was used as an outgroup in both parsimony and Bayesian analysis.

\section{Discussion}

We observed that $M$. azedarach and M. dubia have morphologically distinguishable characters, but information on their genetic variations is lacking. Recently, DNA barcoding has been extensively utilized to confirm species level identification and to resolve taxonomically complex groups based on genetic divergence (Song et al. 2009; Ragupathy et al. 2009; Pang et al. 2011; Nithaniyal and Parani 2016). Therefore, DNA barcoding was employed as a tool to resolve species complexity between M. azedarach and M. dubia. An ideal DNA barcode region should have lower variability within a species than between the congeneric species (Taberlet et al. 2007). Therefore, three chloroplast markers and one nuclear marker, which were reported as efficient DNA barcodes for species differentiation, were used in this study.

Ten accessions of $M$. azedarach and M. dubia were collected from geographically distant locations and they showed fidelity to the respective species as indicated by low level of intra-specific and high level of inter-specific divergence. Even though all the four markers were able to differentiate the two species, considering the level of divergence, ITS2 was found to be the most promising DNA barcode for species differentiation. Earlier studies on taxonomic classification of various congeneric species have also reported ITS2 as the best candidate for species identification with high genetic divergence (Coleman 2003; Yao et al. 2010; Dong et al. 2011; Umapathy et al. 2015). In addition, there was also length variation between the two species with regard to trnH-psbA and ITS2 markers. Combining all the four DNA barcode markers, $M$. azedarach and $M$. dubia showed $8.5 \%$ inter-specific divergence, which is unlikely if they belong to the same species. In the parsimony analysis using the data 
from individual markers, the accessions of M. azedarach and M. dubia bifurcated into two distinct clades in all the markers, except the $r b c L$ marker. No accession from $M$. azedarach was intermixed with the clades of $M$. dubia and vice versa. Bayesian analysis of the concatenated dataset clearly resolved M. azedarach and M. dubia as distinct lineages and there was an unresolved polytomy of $M$. dubia with $M$. volkensii in the root of the genus Melia. This may be due to a poor contribution of the $r b c L$ marker (less divergent) in the absence of retrieved data for trnH-psbA and ITS2 markers. But the clades are supported with high PP values compared the independent datasets. Within the M. azedarach clade, there are two lineages, which may be due to sharing of native and introduced germplasms. But one cannot derive such relationships conclusively from the current study with limited data from world populations. An earlier study based on SRAP markers also reported the existence of significant intra-specific genetic polymorphism in the M. azedarach populations from China (Liao et al. 2016). These observations indicated genetic complexity within M. azedarach, which requires further study.

Species differentiation in Melia is difficult when it is only based on vegetative characters. Accurate methods for selection of species for agro-forestry, silviculture and medicinal uses are necessary. The present study shows that the ITS2 DNA barcode marker could be used as a species-specific marker for confirming species identity. In addition, the DNA barcodes will be much more helpful in authentication of Melia-derived materials that are traded, including raw drugs and commercial timber.

\section{Acknowledgments}

We acknowledge the financial support from SRM-DBT Partnership Platform for Contemporary Research Services and Skill Development in Advanced Life Sciences Technologies (Order No. BT/PR12987/INF22 / 205 / 2015). U.S. was supported by Science and Engineering Research Board, DST (SERB/PDF/2015/000935/LS). 


\section{Conflict of interest}

The authors declare that they have no conflict of interest.

\section{References}

Ahmed, M.F., Raoa, S., Ahemad S.R., and Ibrahim, M. 2012. Phytochemical studies and antioxidant activity of Melia azedarach Linn. leaves by DPPH scavenging assay. Int. J. Pharm. Appl. 3: 271-276.

Cavanilles, A.J. 1789. Monadelphiae Classis Dissertationes Decem. Diss. 7, Septima Dissertation Botanica, Quatuordecim Genera Monadelpha Continens. pg.175.

Chen, S., Yao, H., Han, J., Liu, C., Song, J., Shi, L., Zhu, Y., Ma, X., Gao, T., Pang, X., Luo, K., Li, Y., Li, X., Jia, X., Lin, Y., and Leon, C. 2010. Validation of the ITS2 region as a novel DNA barcode for identifying medicinal plant species. PLoS One, 5(1): e8613. doi: 10.1371/journal.pone.0008613

Coleman, A.W. 2003. ITS2 is a double-edged tool for eukaryote evolutionary comparisons. Trends Genet. 19: 370-375. doi: 10.1016/S0168-9525(03)00118-5

Dassanayake, M.D. 1995. Flora of Ceylon. Vol. 9, pg. 276-278. Oxford and IBH publisher Co., New Delhi, India.

De Jussieu 1830 Mémoires du Muséum d'histoire naturelle, Sur Le Groupe Des Méliacées. Vol. 19. Pg.297

Devey, D.S., Chase, M.W., and Clarkson, J.J. 2009. A stuttering start to plant DNA barcoding: microsatellites present a previously overlooked problem in non-coding plastid regions. Taxon, 58:7-15.

Dharmalingam, S.R., Madhappan, R., Chidambaram, K., Ramamurthy, S., Gopal, K., Swetha, P., and Kumar, K.L.S. 2014. Anti-urolithiatic activity of Melia azedarach Linn leaf extract in ethylene glycol-induced urolithiasis in male albino rats. Trop. J. Pharm. Res. 13: 391-397. doi: 10.4314/tjpr.v13i3.12

Dong, L.N., Wortley, A.H., Wang, H., LI, D.-Z., and LU, L. 2011. Efficiency of DNA barcodes for species delimitation: A case in Pterygiella Oliv. (Orobanchaceae). J. Syst. Evol. 49: 189-202. doi: 10.1111/j.1759-6831.2011.00124.x

Edgar, R.C. 2004. MUSCLE: multiple sequence alignment with high accuracy and high throughput. Nucleic Acids Res. 32 (5), 1792-1797.

Fazekas, A.J., Burgess, K.S., Kesanakurti, P.R., Graham, S.W., Newmaster, S.G., Husband, B.C., Percy, D.M., Hajibabaei, M., and Barrett, S.C. 2008. Multiple multilocus DNA 
barcodes from the plastid genome discriminate plant species equally well. PLoS One, 3(7): e2802. doi: 10.1371/journal.pone.0002802

Gamble, J.S. 1922. A manual of Indian timbers. Reprinted by Bishen Singh and M.P. Singh 2008, Dehradun, India.

Gamble, J.S. 1915. Flora of the presidency of madras. Reprinted by Bishen Singh and M.P. Singh 2008, Dehradun, India.

Ghosh, R.B. 1968. Studies on the morphology of somatic chromosomes in Walsura piscidia Roxb. Caryologia, 21: 111-114. doi: 10.1080/00087114.1968.10796289

Gopal, V., Prakash, Y.G., and Manju, P. 2015. A concise review on Melia dubia Cav. (Meliaceae). Eur. J. Environ. Ecol. 2: 57-60.

Hajra, P.K., Nair, V.J., and Daniel, P. (Editors) 1997. Flora of India (MalpighiaceaeDichapetalaceae), vol. 4, Botanical Survey of India publisher, Calcutta, India.

Han, J., Zhu, Y., Chen, X., Liao, B., Yao, H., Song, J., Chen, S., and Meng, F. 2013. The short ITS2 sequence serves as an efficient taxonomic sequence tag in comparison with the full-length ITS. BioMed Res. Int. 2013: 1-7. doi:10.1155/2013/741476

Hasegawa, M., Matsumura, J., Kusano, R., Tsushima, S., Sasaki, Y., and Oda, K. 2010. Acoustoelastic effect in Melia azedarach for non destructive stress measurement. Constr. Build. Mater. 24: 1713-1717. doi: 10.1016/j.conbuildmat.2010.02.018

Hebert, P.D.N., Cywinska, A., Ball, S.L., and deWaard, J.R. 2003. Biological identifications through DNA barcodes. Proc. R. Soc. Lond. B Biol. Sci. 270: 313-21. doi: 10.1098/rspb.2002.2218

Heckenhauer, J., Barfuss, M.H.J., and Samuel, R. 2016. Universal Multiplexable matK Primers for DNA Barcoding of Angiosperms. Appl. Plant Sci. 4: 1500137. doi: 10.3732/apps. 1500137

Hollingsworth, P.M. 2011. Refining the DNA barcode for land plants. Proc. Natl. Acad. Sci. U.S.A. 108: 19451-19452. doi: 10.1073/pnas.1116812108

Husain, M.K., and Anis, M. 2009. Rapid in vitro multiplication of Melia azedarach L. (a multipurpose woody tree). Acta Physiol. Plant. 31: 765-772. doi: 10.1007/s11738-0090290-7

Kamaraj, C., Rahuman, A.A., Bagavan, A., Mohamed, M.J., Elango, G., Rajakumar, G., Zahir, A.A., Santhoshkumar, T., and Marimuthu, S. 2010. Ovicidal and larvicidal activity of crude extracts of Melia azedarach against Haemonchus contortus (Strongylida). Parasitol. Res. 106: 1071-1077. doi: 10.1007/s00436-010-1750-0 
Kress, W.J., Wurdack, K.J., Zimmer, E.A., Weigt, L.A., and Janzen, D.H. 2005. Use of DNA barcodes to identify flowering plants. Proc. Natl. Acad. Sci. U.S.A. 102: 8369-74. doi: 10.1073/pnas.0503123102

Kumar, R., Singh, R., Meera, P.S., and Kalidhar, S.B. 2003. Chemical components and insecticidal properties of Bakain (Melia azedarach L.)-A review. Agric. Rev. 24: 101115 .

Lake, M. 2015. Australian Rainforest Woods: Characteristics, Uses and Identification. CSIRO Publishing, Australia.

Liao, B., Wang, F., Chen, L., Li, P., Ouyang, K., Pian, R., Liu, M., Que, Q., Zhou, X., Xi, W., and Chen, X. 2016. Population structure and genetic relationships of Melia Taxa in China assayed with sequence-related amplified polymorphism (SRAP) markers. Forests, 7: 1-15. doi: 10.3390/f7040081

Linnaeus, C. 1738. Hortus Cliffortianus, Classis X. Decandria. pg.161.

Liu, J., Yan, H.F., and Ge, X.J. 2016. The use of DNA barcoding on recently diverged species in the genus Gentiana (Gentianaceae) in China. PLoS One, 11(4): e0153008. doi: 10.1371/journal.pone.0153008

Mabberley, D.J. 1984. A monograph of Melia in Asia and the Pacific. The history of white cedar and Persian lilac. Gard. Bull. Sing. 37: 49-64.

Meier, R., Shiyang, K., Vaidya, G., and Ng, P.K.L. 2006. DNA barcoding and taxonomy in Diptera: a tale of high intraspecific variability and low identification success. Syst. Biol. 55: 715-728. doi: 10.1080/10635150600969864

Mulanda, E.S., Awori, R.M., Chuhila, Y., Adero, M.O., Amugune, N.O., Akunda, E., and Kinyamario, J.I. 2016. A DNA-barcode for Melia volkensii Grke (Meliaceae) and its phylogenetic relationship with some economically important relatives. Afr. J. Plant Sci. 10: 58-67. doi: 10.5897/AJPS2015.1385

Murugesan, S., Senthilkumar, N., Rajeshkannan, C., and Vijayalakshmi, K.B. 2013. Phytochemical characterization of Melia dubia for their biological properties. Der. Chem. Sin. 4: 36-40.

Nagalakshmi, M.A.H., Thangadurai, D., Anuradha, T., and Pullaiah, T. 2001. Essential oil constituents of Melia dubia, a wild relative of Azadirachta indica growing in the Eastern Ghats of Peninsular India. Flavour Fragr. J. 16: 241-244. doi:10.1002/ffj.986

Nagalakshmi, M.A.H., Thangadurai, D., and Pullaiah, T. 2003. In vitro antimicrobial efficacy of leaf essential oils of Chukrasia tabularis Adr. Juss. and Melia dubia Cav. (Meliaceae). Phyther. Res. 17: 414-416. doi: 10.1002/ptr.1147 
Nithaniyal, S., Newmaster, S.G., Ragupathy, S., Krishnamoorthy, D., Vassou, S.L., and Parani, M. (2014) DNA barcode authentication of wood samples of threatened and commercial timber trees within the tropical dry evergreen forest of India. PLoS ONE, 9(9): e107669. doi:10.1371/journal.pone.0107669

Nithaniyal, S., and Parani, M. 2016. Evaluation of chloroplast and nuclear DNA barcodes for species identification in Terminalia L. Biochem. Syst. Ecol. 68: 223-229. doi: 10.1016/j.bse.2016.08.001

Pang, X., Song, J., Zhu, Y., Xu, H., Huang, L., and Chen, S. 2011. Applying plant DNA barcodes for Rosaceae species identification. Cladistics, 27: 165-170. doi: 10.1111/j.1096-0031.2010.00328.x

Ragupathy, S., Newmaster, S.G., Murugesan, M., and Balasubramaniam, V. 2009. DNA barcoding discriminates a new cryptic grass species revealed in an ethnobotany study by the hill tribes of the Western Ghats in southern India. Mol. Ecol. Resour. 9: 164171. doi: 10.1111/j.1755-0998.2009.02641.x

Rawat, S., Joshi, G., Annapurna, D., Arunkumar, A.N., and Karaba, N.N. 2016. Standardization of DNA extraction method from mature dried leaves and ISSR-PCR conditions for Melia dubia Cav . - A fast growing multipurpose tree species. Am. J. Plant Sci. 7: 437-445.

Ronquist, F., Teslenko, M., van der Mark, P., Ayres, D.L., Darling, A., Höhna, S., Larget, B., Liu, L., Suchard, M.A., and Huelsenbeck, J.P. 2012. MrBayes 3.2: Efficient Bayesian Phylogenetic Inference and Model Choice Across a Large Model Space. Syst. Biol. 61(3): 539-542. doi:10.1093/sysbio/sys029.

Saghai-Maroof, M., Soliman, K.M., Jorgensen, R., and Allard, R.W. 1984. Ribosomal DNA spacer-length polymorphisms in barley: Mendelian inheritance, chromosomal location, and population dynamics. Proc. Natl. Acad. Sci. U.S.A. 81: 8014-8018. doi: 10.1073/pnas.81.24.8014

Saravanan, V., Parthiban, K.T., Kumar, P., and Marimuthu, P. 2013. Wood characterization studies on Melia dubia cav. for pulp and paper industry at different age gradation. Res. J. Recent. Sci. 2 ISC-201: 183-188.

Sasidharan, N., and Sivarajan, V.V. 1996. Flowering plants of Thrissur forests. Scientific Publishers, Jodhpur, India.

Sharma, D., and Singla, D.Y.P. 2013. Preliminary and pharmacological profile of Melia azedarach L.: An overview. J. Appl. Pharm. Sci. 3: 133-138. doi: 10.7324/JAPS.2013.31224 
Sharma, S.K., Shukla, S.R., Sujatha, M., Shashikala, S., and Kumar, P. 2012. Assessment of certain wood quality parameters of selected genotypes of Melia dubia Cav. grown in a seedling seed orchard. J. Indian Acad. Wood Sci. 9: 165-169. doi: 10.1007/s13196-012$0083-2$

Song, J., Yao, H., Li, Y., Li, X., Lin, Y., Liu, C., Han, J., Xie, C., and Chen S. 2009. Authentication of the family Polygonaceae in Chinese pharmacopoeia by DNA barcoding technique. J. Ethnopharmacol. 124: 434-439. doi: 10.1016/j.jep.2009.05.042

Sundar, P., Nithaniyal, S., Raju, B., and Parani, M. 2016. Multi-locus DNA barcoding identifies matK as suitable marker for species identification in Hibiscus L. Genome, 59(12): 1150-1156

Swofford, D.L. 2002. PAUP*. Phylogenetic analysis using parsimony (*and other methods). Version 4.0b10. Sinauer Associates, Sunderland.

Taberlet, P., Coissac, E., Pompanon, F., Gielly, L., Miquel, C., Valentini, A., Vermat, T., Corthier, G., Brochmann, C., and Willerslev, E. 2007. Power and limitations of the chloroplast trnL (UAA) intron for plant DNA barcoding. Nucleic Acids Res. 35(3): e14. doi: $10.1093 / \mathrm{nar} / \mathrm{gk} 1938$

Umapathy, S., Duvuru, N., Munivenkatappa, S., Ramanan, U.S., and Gudasalamani, R. 2015. Species delimitation in congenerics of Genus Daemonorops from India using DNA barcodes. Commun. Plant. Sci. 5: 1-8.

Vassou, S.L., Kusuma, G., and Parani, M. 2015. DNA barcoding for species identification from dried and powdered plant parts: a case study with authentication of the raw drug market samples of Sida cordifolia. Gene, 559(1): 86e93.

Yao, H., Song, J., Liu, C., Luo, K., Han, J., Li, Y., Pang, X., Xu, H., Zhu, Y., Xiao, P., and Chen, S. 2010. Use of ITS2 region as the universal DNA barcode for plants and animals. PLoS One, 5(10): e13102. doi: 10.1371/journal.pone.0013102

Zhang, W., Chen, Z., Li, J., and Chen, H. 2003. Phylogeny of the Dipsacales s. 1. based on chloroplast $t r n$ L-F and $n d h$ F sequences. Mol. Phylogenet. Evol. 26: 176-189. 


\section{Figure caption}

Fig. 1: Bayesian phylogeny of genus Melia based on concatenated dataset of four markers using MrBayes 3.2. Highlight with color shows the cladogenesis of both Melia azedarach clade (Clade 1) and the clade with Melia dubia and M. volkensii (Clade 2). The posterior probabilities values in percentage are shown at the nodes. The arrow indicates the created polytomy of the Melia dubia accessions with the M. volkensii accession. 
Table 1. Morphological characters of Melia azedarach L. and Melia dubia Cav.

\begin{tabular}{|c|c|c|}
\hline Characters & Melia azedarach & Melia dubia \\
\hline Habit & Deciduous tree, to $11 \mathrm{~m}$ tall & Deciduous tree, to $25 \mathrm{~m}$ tall \\
\hline Bark & $\begin{array}{l}\text { Dark brown, thick and deeply } \\
\text { exfoliate }\end{array}$ & $\begin{array}{l}\text { Dark brown, smooth, exfoliating in thin } \\
\text { narrow strips }\end{array}$ \\
\hline Branchlets & $\begin{array}{l}\text { Scurfy-tomentose, glabrous when } \\
\text { mature }\end{array}$ & $\begin{array}{l}\text { Scurfy-tomentose, glabrous when } \\
\text { mature }\end{array}$ \\
\hline Leaves & 2-3-pinnate, 30-90 cm long & 2-3-pinnate, $>1 \mathrm{~m}$ long \\
\hline Pinnae & $3-8$ pairs, usually opposite, $20-30 \mathrm{~cm}$ & $3-8$ pairs, usually opposite, $20-30 \mathrm{~cm}$ \\
\hline $\begin{array}{l}\text { Leaflets } \\
\text { shape and } \\
\text { size }\end{array}$ & $\begin{array}{l}\text { 5-9 on each pinna, ovate-lanceolate or } \\
\text { elliptic-lanceolate, oblique at base, } \\
\text { toothed or lobed at margins, acuminate at } \\
\text { apex, } 2.5-5 \times 1-2.5 \mathrm{~cm}\end{array}$ & $\begin{array}{l}5-13 \text { on each pinna, ovate to lanceolate, } \\
\text { oblique at base, serrulate or entire at } \\
\text { margins, acuminate at apex, } 3-12 \times 1.5- \\
4 \mathrm{~cm}\end{array}$ \\
\hline $\begin{array}{l}\text { Secondary } \\
\text { nerves }\end{array}$ & 8-15 pairs & 6-16 pairs \\
\hline Petiolules & c. $5 \mathrm{~mm}$ long, longer in terminal leaflet & c. $5 \mathrm{~mm}$ long, longer in terminal leaflet \\
\hline Inflorescence & Panicle, 15-20 cm long, axillary & Panicle, 12-20 cm long, axillary \\
\hline Flowers $^{*}$ & Deep purple (lilac), honey-scented & White, inodorous \\
\hline Pedicle & Slender, to $7 \mathrm{~mm}$ long & Slender, to $7 \mathrm{~mm}$ long \\
\hline Calyx & $\begin{array}{l}\text { 5-lobed; lobes ovate-oblong, pubescent } \\
\text { without }\end{array}$ & $\begin{array}{l}\text { 5-lobed; lobes ovate-oblong, } \\
\text { Tomentose }\end{array}$ \\
\hline Corolla & $\begin{array}{l}5 \text {, linear-oblong, deflexed, } c .8 \mathrm{~mm} \text { long, } \\
\text { pubescent without when young, glabrous }\end{array}$ & $\begin{array}{l}5 \text {, linear-spathulate, concave, } c .5 \mathrm{~mm} \\
\text { long, pubescent on both surfaces }\end{array}$ \\
\hline $\begin{array}{l}\text { Staminal } \\
\text { column }\end{array}$ & $\begin{array}{l}0.5-1 \mathrm{~cm} \text { long, cylindric, } 20-30 \text {-toothed, } \\
\text { purple. }\end{array}$ & $\begin{array}{l}0.5-1 \mathrm{~cm} \text { long, gibbous at base, } 10- \\
\text { toothed, nearly glabrous within, white }\end{array}$ \\
\hline Anther & $\begin{array}{l}\text { Oblongoid, shorter then lobe, apiculate, } \\
\text { pubesent }\end{array}$ & $\begin{array}{l}\text { Oblongoid, at mouth of tube, apiculate, } \\
\text { pubescent }\end{array}$ \\
\hline Ovary & $\begin{array}{l}\text { Ovoid-subglobose, glabrous; 3-loculed; } \\
\text { ovules } 2 \text { in each cell }\end{array}$ & $\begin{array}{l}\text { Ovoid-subglobose, glabrous; 3-loculed; } \\
\text { ovules } 2 \text { in each cell }\end{array}$ \\
\hline Style & $\begin{array}{l}\text { Cylindric, clavate at apex, longer than } \\
\text { staminal tube, apiculate }\end{array}$ & $\begin{array}{l}\text { Cylindric, clavate at apex, longer than } \\
\text { staminal tube }\end{array}$ \\
\hline Stigma & 3-5-fid, truncate & 3-5-fid, truncate \\
\hline Drupe ${ }^{*}$ & $\begin{array}{l}\text { Globose-ellipsoid, } 1-1.5 \times 0.8-1 \mathrm{~cm} \text {, } \\
\text { bright yellow when ripe, } 1 \text {-seeded }\end{array}$ & $\begin{array}{l}\text { Ovoid-ellipsoid, } 2.5-4 \text { x 2-2.5 cm, } \\
\text { yellowish when ripe, pendulous, } 1-4- \\
\text { seeded }\end{array}$ \\
\hline
\end{tabular}

"Key morphological characters based on Hajra et al. (1997) 
Table 2. Details of accessions of Melia azedarach L., Melia dubia Cav., and Azadirachta indica A. Juss. collected from different part of India

\begin{tabular}{|c|c|c|c|c|c|}
\hline $\begin{array}{l}\text { Voucher } \\
\text { ID }\end{array}$ & $\begin{array}{l}\text { Name of the } \\
\text { species }\end{array}$ & District & State & $\begin{array}{l}\text { BOLD } \\
\text { accession No. }\end{array}$ & $\begin{array}{l}\text { GPS } \\
\text { Coordinates }\end{array}$ \\
\hline B0093A & M. azedarach & Chennai & Tamil Nadu (TN1) & SRM001018A & $12^{\circ} 51^{\prime} \mathrm{N}, 80^{\circ} 03^{\prime} \mathrm{E}$ \\
\hline B0093B & M. azedarach & Cuddalore & Tamil Nadu (TN2) & SRM001018B & $11^{\circ} 32^{\prime} \mathrm{N}, 79^{\circ} 28^{\prime} \mathrm{E}$ \\
\hline B0093C & M. azedarach & Villupuram & Tamil Nadu (TN3) & SRM001018C & $11^{\circ} 47^{\prime} \mathrm{N}, 79^{\circ} 24^{\prime} \mathrm{E}$ \\
\hline B0093D & M. azedarach & West Godavari & Andhra Pradesh (AP) & SRM001018D & $16^{\circ} 39^{\prime} \mathrm{N}, 81^{\circ} 31^{\prime} \mathrm{E}$ \\
\hline B0093E & M. azedarach & Thrissur & Kerala (KL) & SRM001018E & $8^{\circ} 32^{\prime} \mathrm{N}, 76^{\circ} 55^{\prime} \mathrm{E}$ \\
\hline B0093F & M. azedarach & Kolhapur & Maharashtra (MH) & SRM001018F & $16^{\circ} 42^{\prime} \mathrm{N}, 74^{\circ} 16^{\prime} \mathrm{E}$ \\
\hline B0093G & M. azedarach & Amroha & Uttar Pradesh (UP) & SRM001018G & $28^{\circ} 50^{\prime} \mathrm{N}, 78^{\circ} 14^{\prime} \mathrm{E}$ \\
\hline B0093H & M. azedarach & Howrah & West Bengal (WB) & SRM001018H & $22^{\circ} 33^{\prime} \mathrm{N}, 88^{\circ} 17^{\prime} \mathrm{E}$ \\
\hline B0093I & M. azedarach & Indore & Madhya Pradesh (MP) & SRM001018I & $22^{\circ} 45^{\prime} \mathrm{N}, 75^{\circ} 53^{\prime} \mathrm{E}$ \\
\hline B0093J & M. azedarach & Hassan & Karnataka (KA) & SRM001018J & $13^{\circ} 00^{\prime} \mathrm{N}, 77^{\circ} 26^{\prime} \mathrm{E}$ \\
\hline B1080A & M. dubia & Chennai & Tamil Nadu (TN1) & SRM001020A & $12^{\circ} 49^{\prime} \mathrm{N}, 80^{\circ} 02^{\prime} \mathrm{E}$ \\
\hline B1080B & M. dubia & Chennai & Tamil Nadu (TN2) & SRM001020B & $12^{\circ} 49^{\prime} \mathrm{N}, 80^{\circ} 02^{\prime} \mathrm{E}$ \\
\hline B1080C & M. dubia & Chennai & Tamil Nadu (TN3) & SRM001020C & $12^{\circ} 49^{\prime} \mathrm{N}, 80^{\circ} 02^{\prime} \mathrm{E}$ \\
\hline B1080D & M. dubia & West Godavari & Andhra Pradesh (AP) & SRM001020D & $16^{\circ} 32^{\prime} \mathrm{N}, 80^{\circ} 34^{\prime} \mathrm{E}$ \\
\hline B1080E & M. dubia & Thrissur & Kerala (KL) & SRM001020E & $8^{\circ} 32^{\prime} \mathrm{N}, 76^{\circ} 55^{\prime} \mathrm{E}$ \\
\hline B1080F & M. dubia & Kolhapur & Maharashtra (MH) & SRM001020F & $16^{\circ} 42^{\prime} \mathrm{N}, 74^{\circ} 15^{\prime} \mathrm{E}$ \\
\hline B1080G & M. dubia & Amroha & Uttar Pradesh (UP) & SRM001020G & $28^{\circ} 50^{\prime} \mathrm{N}, 78^{\circ} 14^{\prime} \mathrm{E}$ \\
\hline B $1080 \mathrm{H}$ & M. dubia & Howrah & West Bengal (WB) & SRM001020H & $22^{\circ} 33^{\prime} \mathrm{N}, 88^{\circ} 17^{\prime} \mathrm{E}$ \\
\hline B1080I & M. dubia & Indore & Madhya Pradesh (MP) & SRM001020I & $22^{\circ} 45^{\prime} \mathrm{N}, 75^{\circ} 53^{\prime} \mathrm{E}$ \\
\hline B 1080J & M. dubia & Hassan & Karnataka (KA) & SRM001020J & $13^{\circ} 00^{\prime} \mathrm{N}, 77^{\circ} 26^{\prime} \mathrm{E}$ \\
\hline B0103A & A. indica & Chennai & Tamil Nadu (TN1) & SRM001019A & $12^{\circ} 49^{\prime} \mathrm{N}, 80^{\circ} 02^{\prime} \mathrm{E}$ \\
\hline B0103B & A. indica & Cuddalore & Tamil Nadu (TN2) & SRM001019B & $11^{\circ} 32^{\prime} \mathrm{N}, 79^{\circ} 28^{\prime} \mathrm{E}$ \\
\hline B0103C & A. indica & Villupuram & Tamil Nadu (TN3) & SRM001019C & $11^{\circ} 47^{\prime} \mathrm{N}, 79^{\circ} 24^{\prime} \mathrm{E}$ \\
\hline
\end{tabular}




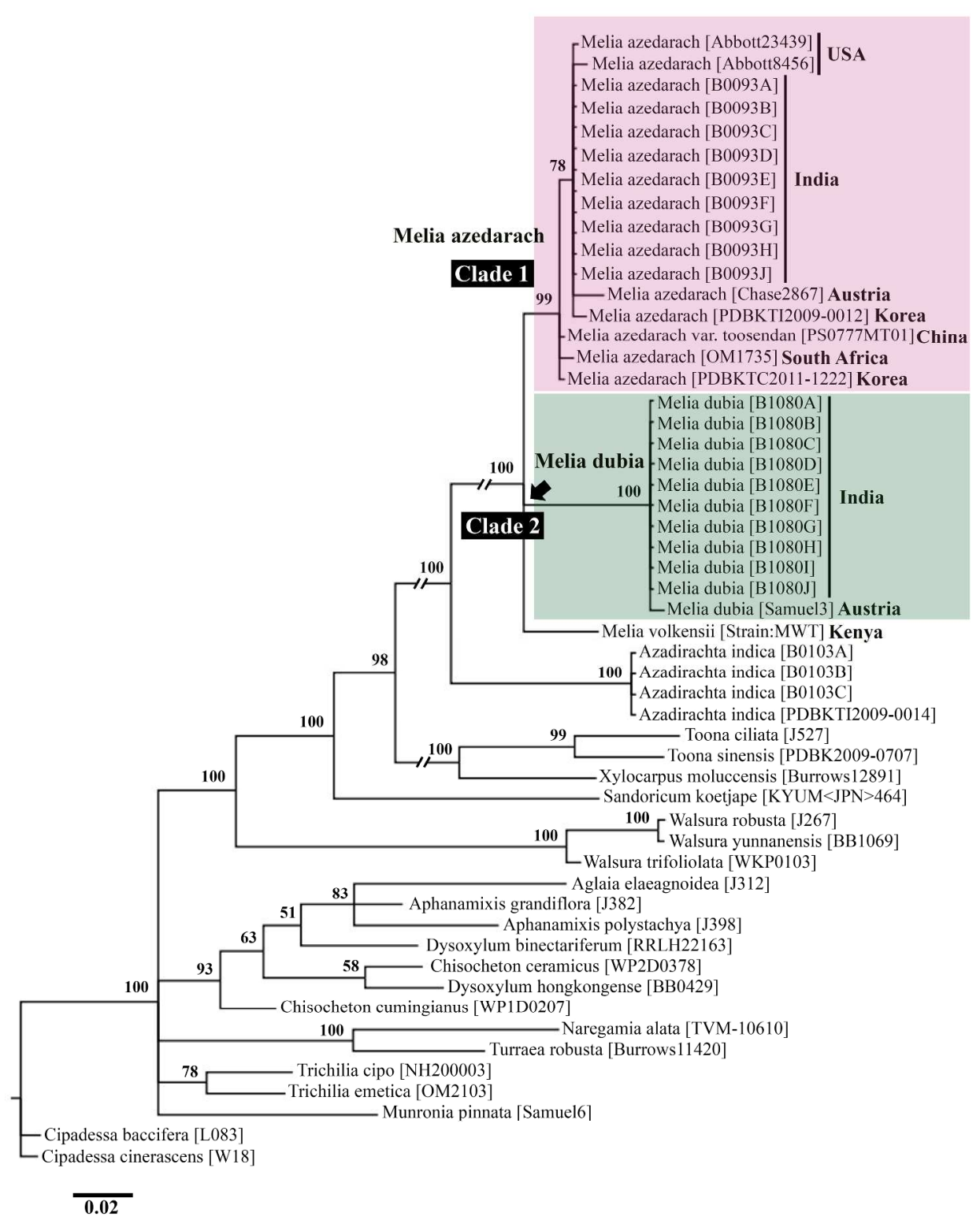

Fig. 1: Bayesian phylogeny of genus Melia based on concatenated dataset of four markers using MrBayes 3.2. Highlight with color shows the cladogenesis of both Melia azedarach clade (Clade 1) and the clade with Melia dubia and M. volkensii (Clade 2). The posterior probabilities values in percentage are shown at the nodes. The arrow indicates the created polytomy of the Melia dubia accessions with the M. volkensii accession.

$262 \times 329 \mathrm{~mm}(300 \times 300 \mathrm{DPI})$ 